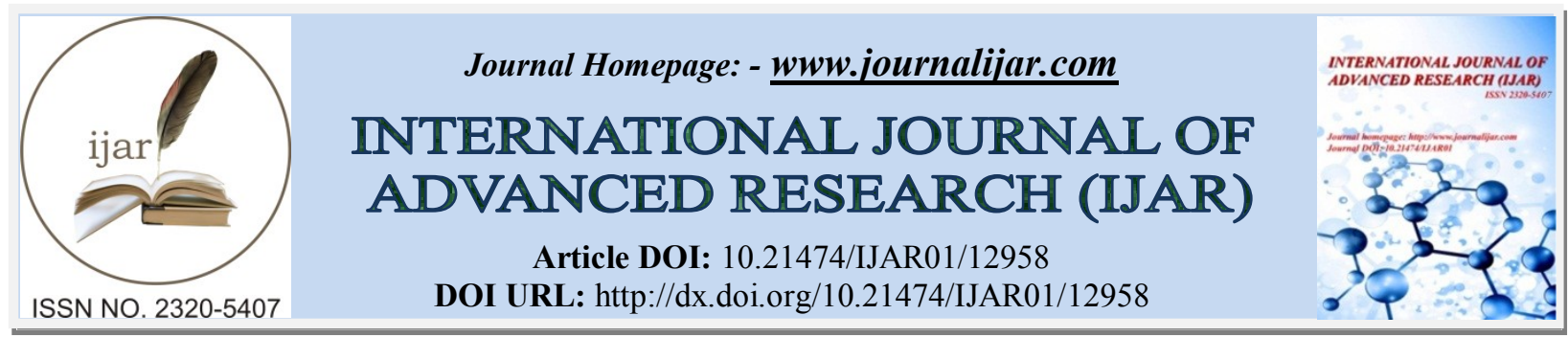

RESEARCH ARTICLE

\title{
RELATIONSHIP ENVIRONMENTAL SANITATION WITH THE INCIDENT OF PULMONARY TUBERCULOSISIN PUBLIC HEALTH CENTER SIKAKAP MENTAWAI ISLANDS
}

Weni Sartiwi and Rhona Sandra

High School of Health Sciences SyedzaSaintika Padang, West Sumatera, Indonesia.

\section{Manuscript Info}

(...........................

Manuscript History

Received: 30 March 2021

Final Accepted: 30 April 2021

Published: May 2021

Key words:-

Pulmonary Tuberculosis, Environmental

Sanitation

\begin{abstract}
Background:The achievement of countermeasures for tuberculosis treatment in Mentawai Islands District is still very low. This can be seen from the cure rate for new smear positive cases in 2016, which has not reached the target of $84.44 \%$. While the data shows that of the 10 existing Puskesmas in Mentawai Islands District, the highest incidence of pulmonary Tuberculosis in Sikakap Health Center is 51 people. This study aims to determine the relationship between environmental sanitation with the incidence of pulmonary TB in Sikakap Health Center Mentawai Islands District in 2018.

Methodology:This type of research is descriptive with a cross sectional study method. The population was all patients who visited the Sikakap Health Center who were examined by doctors the last 3 months (January to March 2018) totaling 315 people. A sample of 42 people was taken by simple random sampling method. Data collection was carried out through interviews using interview guidelines in the form of a questionnaire. Data analysis was univariate and bivariate using chisquare test.

Results:Based on the results of the study found $59.5 \%$ of respondents experienced pulmonary Tuberculosis, $64.3 \%$ of respondents had environmental sanitation that did not meet the requirements. Statistically obtained the relationship between environmental sanitation with the incidence of pulmonary TB in Sikakap Public Health Center in Mentawai Islands District in $2018(\mathrm{p}=0,024)$.

Conclusion:Thereisasignificantcorrelationbetweenenvironmental sanitation with the incidence of pulmonary Tuberculosis. It is expected that health workers through the holder of the Pulmonary TB program to better screen patients who drop out of medication and improve counseling about prevention of pulmonary Tuberculosis.
\end{abstract}

Copy Right, IJAR, 2021,. All rights reserved.

\section{Introduction:-}

Pulmonary tuberculosis (TB) is the third leading cause of death in the world after heart and respiratory disease and is the number one cause of infectious diseases. In 2014 there were 9.6 million people in the world infected with TB germs and in 2014, the highest number of pulmonary TB cases was in the African region (37\%), the Southeast Asia region (28\%), and the East Mediterranean region $(17 \%)^{(1)}$. The prevalence of pulmonary tuberculosis in Indonesia is grouped into three regions, namely the Sumatra region (33\%), the Java and Bali regions (23\%), and the eastern part of Indonesia (44\%). Pulmonary tuberculosis is the third leading cause of death after heart and respiratory disease in 
all age groups and number one for infectious diseases. The death toll from pulmonary TB in Indonesia is estimated at 61,000 deaths each year ${ }^{(2)}$.

The incidence of pulmonary tuberculosis in West Sumatra continues to increase every year, namely in 2013 as many as 3660 cases, in 2014 as many as 3896 cases, in 2015 as many as 3914 cases, and in 2016 there were found as many as 3926 cases spread across 19 districts / cities in Sumatra Province. West including the Mentawai Islands Regency (3)

Data from the Health Office of the Mentawai Islands Regency in 2017, shows that the achievement of tuberculosis treatment control is still very low, both at the Puskesmas and at the hospital. This can be seen from the cure rate for new cases of BTA positive in 2016 that has not reached the target, namely $84.44 \%$. The discovery of new positive BTA cases in 2017 has not yet reached the target of $67.88 \%$ of the target of $70 \%$. Meanwhile, the data shows that out of 10 Puskesmas in Mentawai Islands Regency, the highest incidence of pulmonary TB was found in PuskesmasSikakap, namely 51 people ${ }^{(3)}$.

The success or failure of tuberculosis treatment depends on environmental sanitation and the family economy. There is no effort from yourself or motivation from the family who do not provide support for complete treatment will affect patient adherence to taking the drug. If this is allowed, the impact that will arise if the patient stops taking the drug is the emergence of tuberculosis germs that are resistant to drugs, if this continues and the germs continue to spread, controlling tuberculosis drugs will be increasingly difficult to implement and the increasing death rate continues to increase due to tuberculosis ${ }^{(4)}$. Poor housing, environment and workplace sanitation can facilitate transmission of pulmonary tuberculosis ${ }^{(5)}$.

Pulmonary TB disease is closely related to the sanitation of the home environment, such as lighting conditions, house floors, rooms, ventilation and world density. The sanitation of the home environment greatly affects the presence of the Mycobacterium tuberculosis bacteria, where the Mycobacterium tuberculosis bacteria can live for 12 hours even up to several days to weeks depending on the presence or absence of sunlight ${ }^{(6)}$. A healthy home according to Winslow and APHA (America Public Health Association), must meet several requirements, such as ventilation, rooms, lighting, type of house floor and occupant density ${ }^{(7)}$

Based on the living environment / place of residence, the house is one of the basic human needs which functions as a place to live or shelter. The house has a function as a place to unwind, a place to foster a sense of kinship, a symbol of social status and a place to put or store valuables ${ }^{(7)}$. Density of occupancy and housing conditions ranks second by $70 \%$ after economic status which affects the transmission of pulmonary tuberculosis, which is $90 \%{ }^{(8)}$.

The results of previous research conducted by Hidayati and Pramudya (2015) on the relationship between environmental sanitation and the incidence of pulmonary tuberculosis in Tawangsari Hamlet, Bandarasri Village, Ngoro District, Mojokerto Regency, showed that 89 respondents owned houses. A survey that was conducted in May 2018 by looking directly at 10 houses with pulmonary tuberculosis, it was found that the conditions of the houses did not meet health requirements, including 4 houses with lighting that did not illuminate the entire room, 2 houses with floor types which were partly ground and partly cement., 2 houses with spacious rooms that do not meet the requirements, 1 customary house that does not open ventilation to create good air circulation and 1 house with an occupancy density that exceeds the normal limit, which is more than 2 people in 1 room $^{(9)}$.

\section{Methodology:-}

This type of research is descriptive analytic with a cross sectional design. This research was conducted at the Sikakap Health Center, Mentawai Regency from April to August 2018. The population was all patients who visited the Sikakap Community Health Center totaling 315 people with a sample of 42 people. The sampling technique in this study was simple random sampling, namely simple random sampling using a lottre. Environmental sanitation variables were carried out through interviews with questionnaires, while data collector for pulmonary TB incidence used medical record data. The analysis used was Univariate Bivariate analysis with the chi-square test.

\section{Results:-}

Table1:- Characteristics of Respondents at the Sikakap Health Center Mentawai Islands Regency.

\begin{tabular}{l|l|l|l} 
No. & Karakteristik & f & $\%$
\end{tabular}




\begin{tabular}{|l|l|l|l|}
\hline $\mathbf{1 .}$ & Age & & \\
\hline & $20-35$ & 13 & 31,0 \\
\hline & $>35$ & 29 & 69,0 \\
\hline $\mathbf{2 .}$ & Gender & $\mathbf{f}$ & $\mathbf{\%}$ \\
\hline & Male & 30 & 71,4 \\
\hline & Female & 12 & 28,6 \\
\hline $\mathbf{3 .}$ & Education & $\mathbf{f}$ & $\mathbf{\%}$ \\
\hline & Primary School & 16 & 38,1 \\
\hline & Junior high school & 19 & 45,2 \\
\hline & Senior High School & 7 & 16,7 \\
\hline $\mathbf{4 .}$ & Profesion & $\mathbf{f}$ & $\mathbf{\%}$ \\
\hline & Housewife & 12 & 28,6 \\
\hline & Farmers & 19 & 45,2 \\
\hline & Fisherman & 7 & 16,7 \\
\hline & Entrepreneur & 4 & 9,5 \\
\hline
\end{tabular}

Based on table 1 above, it can be seen that of the 42 respondents more than half of 29 people $(69.0 \%)$ of respondents were $>35$ years old, 30 people $(71.4 \%)$ were male, 19 people $(45.2 \%)$ ) respondents have junior high school education, 19 people $(45.2 \%)$ respondents work as farmers.

Table 2:- Frequency distribution of pulmonary .tuberculosis accident.

\begin{tabular}{|l|l|l|l|}
\hline No. & Pulmonary Tuberculosis Accident & f & \% \\
\hline 1. & Not pulmonary Tuberculosisaccident & 17 & 40,5 \\
\hline 2. & Pulmonary Tuberculosis & 25 & 59,5 \\
\hline & Amount & 42 & 100,0 \\
\hline
\end{tabular}

Based on table 2 above, it can be seen that of the 42 respondents more than half of 25 people (59.5\%) of respondents experienced pulmonary tuberculosis.

Table 3:- Frequency distribution of Environment Sanitation.

\begin{tabular}{|l|l|l|l|}
\hline No. & Environment Sanitation & f & \% \\
\hline 1 & Qualify & 15 & 35,7 \\
\hline 2 & Not Qualify & 27 & 64,3 \\
\hline & Amount & 42 & 100,0 \\
\hline
\end{tabular}

Based on table 3 above, it can be seen that of the 42 respondents, more than half of 27 people (64.3\%) had environmental sanitation that did not meet the requirements.

Table 4:- Relationship Environmental Sanitation With The Incident Of Pulmonary Tuberculosis.

\begin{tabular}{|c|c|c|c|c|c|c|c|c|}
\hline \multirow[t]{3}{*}{ No. } & \multirow{3}{*}{$\begin{array}{l}\text { Environment } \\
\text { Sanitation }\end{array}$} & \multicolumn{4}{|c|}{ Tuberculosis Pulmonary Accident } & \multirow{2}{*}{\multicolumn{2}{|c|}{ Total }} & \multirow[t]{3}{*}{ P value } \\
\hline & & \multicolumn{2}{|c|}{ Not TB Pulmonary } & \multicolumn{2}{|c|}{$\begin{array}{l}\text { Tuberculosis } \\
\text { Pulmonary }\end{array}$} & & & \\
\hline & & f & $\%$ & f & $\%$ & f & $\%$ & \\
\hline 1. & Qualify & 10 & 66,7 & 5 & 33,3 & 15 & 100,0 & 0,024 \\
\hline 2. & Not Qualify & 7 & 25,9 & 20 & 74,1 & 27 & 100,0 & \\
\hline & Amount & 17 & 40,5 & 25 & 59,5 & 42 & 100,0 & \\
\hline
\end{tabular}

Based on table 4 above, it can be seen that the incidence of pulmonary tuberculosis was more prevalent in respondents who had environmental sanitation that did not meet the requirements of 20 people $(74.1 \%)$ than those who met the requirements of 5 people (33.3\%). The results of statistical tests (chi-square) obtained $\mathrm{p}$ value $=0.024$ $(p<0.05)$, which means that there is a relationship between environmental sanitation and the incidence of pulmonary tuberculosis at the Sikakap Health Center, Mentawai Islands Regency. 


\section{Discussion:-}

Based on the results of the study, it was found that of the 42 respondents more than half (59.5\%) of respondents had pulmonary tuberculosis. The results of this study are in line with previous research conducted by Sayogi (2015) on the factors associated with the incidence of pulmonary tuberculosis in Boyolali.Pulmonary TB is an infectious disease caused by the bacteria Mycobacterium Tuberculosis which attacks the lungs and bronchi. Pulmonary TB is classified as an air borne infection, which can enter the human body through breathing air into the lungs ${ }^{(10)}$. Then the germs spread from the lungs to other parts of the body through the circulatory system, lymph system, through the bronchi or other direct spread to the body ${ }^{(6)}$.

Based on the results of the research that has been done, it is found that the number of pulmonary TB patients based on age is the largest age who experiences pulmonary TB disease is $>35$ years old. Based on the results of this study, the researcher found that most cases were in productive age. Productive age is the age when active activities outside the home environment so that it is more at risk of spreading pulmonary TB disease, especially in crowded environments. Age affects a person's body defenses, the higher the age, the lower the person's defense.The impact of the results of the research conducted by the researchers was that pulmonary TB patients who were of productive age were more vulnerable to the risk of contracting pulmonary TB disease because they were more active outside the home environment. Some TB patients who are of productive age, work from morning to midnight which is influenced by weather factors, lack of rest, and lack of nutritious food. Due to the busy activities of pulmonary TB patients, some pulmonary TB patients do not pay attention to their health at least with symptoms of cough $>2$ weeks.

Based on the researcher's analysis, the results of this study showed that more than half of the respondents experienced pulmonary TB incidence, this was due to the high spread of pulmonary TB. Based on the observations of researchers in the field, it was found that there were sanitary conditions in the home environment that did not meet the requirements. This is evident from the results of the environmental sanitation questionnaire on questions about the condition of the house floor that is not waterproof or the floor is made of earth (61.9\%), questions about natural lighting in the living room that does not enter light $(61.9 \%)$ and questions Regarding the source of water used for family toilets comes from the river $(83.3 \%)$.

Based on the results of the study, it was found that of the 42 respondents more than half $(64.3 \%)$ of respondents had environmental sanitation that did not meet the requirements. The results of this study are in line with previous research conducted by Sayogi (2015) regarding the factors associated with the incidence of pulmonary tuberculosis in Boyolali Regency. The results of his research indicate that the sanitary conditions of the home environment are inadequate or inadequate $(60.5 \%$ ). In essence, environmental health is an optimum environmental condition so that it has a positive effect on the realization of an optimal health status which includes: lighting, floor types, rooms, ventilation and occupancy density ${ }^{(10)}$.

According to Indonesia Law No. 4 of 1992 on Housing and Settlements, a house is a place to live or occupy and a means of fostering a family. Meanwhile, what is meant by health according to WHO (World Health Organization) is a condition that is perfect both physically, mentally, and socially and culturally, not only free from disease and weakness. Based on the above understanding, it can be interpreted that a healthy house is a place of shelter and shelter and a place to rest so as to foster a perfect life both physically, spiritually and socio-culture.Based on the researcher's analysis, the results of this study indicate that most of the environmental sanitation conditions in this study do not meet the requirements. From the observations of researchers in the field, it can be seen that the most environmental sanitation that does not meet the requirements is in the sector of floor conditions, lighting and water sources used for latrines. This is evident from the results of the environmental sanitation questionnaire on questions, namely the condition of the house floor that is not watertight or the floor is made of earth (61.9\%), questions about natural lighting in the living room that does not enter light $(61.9 \%)$ and questions Regarding the source of water used for family toilets comes from the river $(83.3 \%)$.

Based on the results of the study, it was found that the incidence of pulmonary tuberculosis was more prevalent in respondents who had environmental sanitation that did not meet the requirements $(74.1 \%)$ than those who met the requirements $(33.3 \%)$. The results of the statistical test (chi-square) obtained $\mathrm{p}$ value $=0.024(\mathrm{p}<0.05)$, which means that there is a relationship between environmental sanitation and the incidence of pulmonary tuberculosis at the Sikakap Health Center, Mentawai Islands Regency in 2018. 
The results of this study are comparable to previous research conducted by Nurcahyo (2013) which found a relationship between home lighting conditions and the incidence of pulmonary tuberculosis ${ }^{(11)}$. This is consistent with the results of a study conducted by Musadad (2001) who conducted a study on the relationship between home environmental factors and the incidence of pulmonary TB transmission in households. the house entered into the $\operatorname{sun}^{(12)}$.

Tuberculosis continues to be a major public health problem causing ill health to approximately 10 million people each year. It is 1 of the 10 causes of death worldwide from a single infectious agent ${ }^{(13)}$.According to Atmosukarto and Soeswati in Nurhidayah in 2007, Mycobacterium tubercolusis can live for years in a cool, humid place without sunlight and Mycobacterium tubercolusis can die when exposed to sunlight. Artificial light is using non-natural light sources, such as kerosene lamps, electricity, fire and so on ${ }^{(14)}$.The occupancy density requirements for all ordinary housing are expressed in $\mathrm{m}^{2}$ per person. The minimum area per person is very relative, depending on the quality of the building and the facilities available. For simple housing, a minimum of $10 \mathrm{~m}^{2} /$ person. For bedrooms, a minimum of 2 people is required. Bedrooms should not be occupied by> 2 people, except for husband and wife and children under two years. If there are family members who suffer from tuberculosis, it is better not to sleep with other family members.

In this study, there are still many houses that are densely populated where the results of the questionnaire were $43 \%$ of respondents had a building area of less than $8 \mathrm{~m} 2$ which was occupied by 2 or more people, this is due to customs where older girls and youngest married girls are not allowed to moving house. Overcrowding is also one of the ways in which infectious diseases can be transmitted to other family members. Density of occupancy greatly affects the transmission of pulmonary tuberculosis, because pulmonary TB germs can be transmitted through air media so that if the house is densely populated these germs are easily transmitted. If the house is not congested, the air circulation becomes smooth so that the patient and other family members can protect the transmission of pulmonary tuberculosis.

In addition, the incidence of pulmonary tuberculosis in the study was also caused by humidity and lighting conditions. According to research by Fatimah (2008) on environmental health factors related to the incidence of pulmonary tuberculosis, it shows that there is a relationship between the incidence of pulmonary tuberculosis and humidity, wall type, ventilation and lighting ${ }^{(15)}$. In theory, environmental sanitation is closely related to residential conditions. Environmental sanitation is an effort to control physical environmental factors that may cause harm to physical development, health and human survival. These control efforts include the provision of good household water, regulation of disposal of feces, garbage, wastewater, regulating healthy homes, eradicating disease vectors such as flies and mosquitoes, monitoring air pollution and radiation from radioactive remains. Family sanitation is measured from three aspects: the physical condition of the house, household facilities and water sources.

\section{Conclusion:-}

There is a significant negative correlation between depression and coping of humor among students inAl Alahsa, Saudi Arabia. Moreover, extraverted participants and emotional stable participants were associated withhigher usage of humor to cope and less level of depression. Depression is a major health disorder and thus a rigorousresearch focusing on understanding depression, treatment techniques and more importantly prevention of depressionshouldbeconducted.

\section{Reference:-}

1. World Health Organization, 2015. Global Tuberculosis Report 2015. Switzerland

2. Ministry of Health, 2017, 2017. Prevalensi TB paru di Indonesia. Jakarta.

3. West Sumatra Health Office, 2017. Profil Kesehatan Propinsi Sumatera Barat Tahun 2017. Padang : Dinkes.

4. Purwanto, 2014.Faktor yang BerpengaruhTerhadapKejadian Tuberkulosis. Jakarta.

5. Manalu, 2010. Faktor-faktor yang MempengaruhiKejadian TB ParudanUpayaPenanggulangannya. JurnalEkologiKesehatan Vol.9 No 4. Desember 2010 : 1340-1346

6. Widyanto, 2013. Keperawatankomunitas. Yogyakarta :NuhaMedika.

7. Almansyah, 2013. PilarDasarIlmuKesehatan. Masyarakat. NuhaMedika. Yogyakarta.

8. Amrullah A.2012. Faktor yang mempengaruhipenularanpenyakit tuberculosis paru. Jakarta.

9. HidayatidanPramudya, 2015. Hubungansanitasilingkungandengankejadian TB paru di SusunTawangsariDesaBandasariKecamatan Ngoro KabupatenMojokerto. JurnalVol II. No 3. 
10. Sayogi, 2015. Faktor-faktor yang berhubungandengankejadian TB Paru di KabupatenBoyolali. Jurnal Penelitian.

11. Nurcahyo, 2013. Hubunganantarakondisipencahayaanrumahdengankejadian TB Paru. Jurnal Penelitian.

12. Musadad, A, 2001. Analisisspasialmasalahpencemaranalingkungandankesehatan (studipendahuluan di kotabanung, dalam http : /digilib.litbang.depkes.go.id

13. Kilaru SC, Prasad S, Kilaru H, Anneela RR, Hasan A, Nandury EC. Active pulmonary tuberculosis presenting with acute respiratory failure. Respirol Case Reports. 2019;7(7):1-5.

14. Notoatdmojo, 2012. Metodologi Penelitian Kesehatan. Jakarta ; Rineka Cipta.

15. Fatimah S,2008. Faktor kesehatan lingkungan rumah yang berhubungan dengan kejadian TB Paru di Kabupaten Cilacap. Tesis Universitas Diponegoro Semarang. 